\title{
Population Administration Service Innovation in Indonesia During the Covid-19 Pandemic
}

\author{
Wisber Wiryanto \\ National Institute of Public Administration
}

\begin{abstract}
The Corona Virus Disease 2019 (Covid-19) pandemic has an impact on changing work patterns around the world. This also includes public services in the population administration (Adminduk) sector in Indonesia. The Ministry of Home Affairs has issued a letter No. 443.1/2978/Dukcapil dated March 16, 2020, concerning Adminduk Services and Virus Corona Diseases (Covid-19) Prevention. This letter was sent to the Head of Population and Civil Registry (Dukcapil) offices in all Province and Regency/City. This letter consists of some instructions to conduct for Adminduk service efficiently and effectively during the Covid-19 pandemic. Therefore, as an implementation this instruction, a study about innovation of Adminduk service during the Covid-19 pandemic to find out innovation by Dukcapil offices. A problem formulation as a research question as follow, what is innovation of Adminduk service can make by Dukcapil offices during the Covid-19 pandemic? The study was conducted in the second quarter of 2020. Research methods using library research, reference, documents, and data which relevant. An accidental sampling technique is used to take 15 Dukcapil offices. Next, secondary data was collected, and analyzing data used qualitative descriptive technique to identify an innovation of Adminduk service. The result of this study showed, the Adminduk service innovations during the Covid-19 pandemic, in 3 (three) types, covering an online application, Covid-19 health protocols, and pickup the ball innovation. The Dukcapil offices are relevant need to copy an Adminduk service innovation alternative types, with accordance according to local condition, for overcome the Covid-19 pandemic constraints, and use them as input for public service can be function in the new-normal era.
\end{abstract}

\section{Keywords:}

population administration; service innovation; the Covid-19 pandemic

\section{Introduction}

The population administration (Adminduk) is an important public service. Because the scope of Adminduk's services is broad, covering population in Indonesia from birth to death. In addition, the dynamics of population change happens day to day also to influence its complexity. Therefore, Adminduk services become the central point for other service fields, including education, health and social services. 
Adminduk services are carried out by Population and Civil Registry (Dukcapil) office spread across all regions in Indonesia, covering 34 (thirty four) provinces; and 416 (four hundred and sixteen) districts; and 98 (ninety eight) cities.

The Policy becomes the reference for Adminduk services, in the form of laws and regulations, as the basis for reference services for Adminduk, includes: (1) Law (UU) No. 24/2013 concerning Amendments to Law No. 23/2006 concerning Adminduk. This law mandates every provincies and regencies/ cities government to carry out administrative affairs properly.

Furthermore, the government has issued technical instructions currently, among others; (2) Regulation of the Ministry of Home Affairs (Permendagri) No. 7/2019 concerning Online Adminduk Services. And, (3) Permendagri No. 96/2019 concerning Data Collection and Issuance of Population Documents for Adminduk Vulnerable Populations. Finally, (4) Letter of the Ministry of Home Affairs (Kemendagri) No. 443.1/2978/Dukcapil dated March 16, 2020, regarding Adminduk Services and Corona Virus Diseases (Covid-19) Prevention. This letter content an instruction for the Head of the Service to prioritize online administration services and the Covid-19 prevention.

However, policy implementation concerning Adminduk services in each Dukcapil offices are varied. Because they are influenced both local problems such as different geographical condition, human and system factors, as well as global problems namely the Covid-19 pandemic.

The Covid-19 pandemic has changed social behavior, and so has social cohesion. The pandemic has a direct impact on the lives of the Indonesian people, so that it has experienced quite dramatic changes. Lifestyles have changed, from the individual level, to the social, cultural, economic, political, and legal levels (LIPI, 2020).

So, the Covid-19 pandemic has an impact on changing work patterns around the world, including public services namely Adminduk services in Indonesia. As a solution, it takes a study and policy recommendations to handle the Covid-19 pandemic, by making an innovation in Adminduk services. Innovation is an introduction of new ways of converting inputs into outputs resulting in changes in increasing the value of benefits (Fontana, A., 2011). Innovation activity is a value creation. In creating this value, innovation must be able to provide added value to welfare (Nasution, A.H. and Kartajaya, H., 2018). 
According to OECD (2019), innovation is a source of growth and a tool for addressing global challenges like climate change and social issues such as inequality. Regions are seeking to promote their economic development increasingly through support to innovation. They define and implement strategies and policy instruments to build on their strengths and to shift course. So, innovation is an important activity carried out by the government by introducing new ways of converting inputs into outputs for development and community welfare.

Innovation is a social process that is strongly influenced by an interaction between stakeholders (Saparita, R., 2015). Meanwhile, according to Dyer, J. (2013), innovative thinkers relate fields, problems, or ideas, which others perceive as unrelated. Therefore, government officials need to take innovation initiatives based on ideas, capabilities in the fields of science and technology, overcome problems faced to find solutions, and change policies, by making innovation decisions. This means, the success of the initiation and implementation of innovation is determined by the government and society, especially in developing innovation for the welfare of the people.

In other words, innovation is a transformation process that converts input (poor people) into output (wellfare society) through the used of innovation. It means, the success of innovation is determined by the success of the change process for the better. Thus, innovation in public sector is a problem solution and policy changes for public service namely Adminduk services so that efficient and effective.

Some problem about Adminduk services, among others: (1) local problems, related to geographical conditions, systems, and human factors; (2) public sector innovation problems; and (3) global problems, namely the Covid-19 pandemic. This problem most influences Adminduk services.

First, the local problems, related to the geographic condition, human factor, and system, as follows: (1) System limitations: (a) IT that is not supportive: weak network with small bandwidth, data is not up to date; (b) Infrastructure: slow computer equipment, limited forms, no waiting room; (c) Long procedural: in the lowest level of government bureaucracy (RT-RW-Kelurahan-Kecamatan-Dinas); (2) Human factors - Moral hazard: (a) Corruptive / opportunistic behavior: illegal fees, bribery, brokers, and discrimination; (b) Weak public participation/ awareness; (c) Officer behavior: not service-oriented; and (d) less capable human resources: lacks competency certification, often mutation (Utomo, T.W.W., 2017); and 
(3) Indonesia has geographical broad conditions too influence problem of Adminduk service in the local area.

Second, public sector innovation problems. According to Mulgan \& Albury (2003), public sector innovation has constraints: (1) reluctance to close down failing programs or organization; (2) over-reliance on high performers as sources of innovation; (3) technologies available but constraining cultural or organizational arrangements; (4) no rewards or incentives to innovate or adopt innovations; (5) poor skills in active risk or change management; (6) short-term budgets and planning horizons); (7) very pressures and administrative burdens); and (8) culture of risk aversion.

Third, global problems, namely the Covid-19 pandemic, have an impact on public sector services and innovation. Early, the Covid-19 pandemic happened in Wuhan, China at the end of 2019. Then, it spread to various countries, many residents who contracted the virus due to direct contact. In the first half of 2020, the pandemic has killed half a million people. as already mentioned (Tempo, 2020). So, the Covid-19 pandemic has an impact on changes in the socio-economic life of the community, including work patterns in Indonesia.

Therefore, the Dukcapil offices are needs to solve problems with a solution through innovation to continuously update the Adminduk services, to improve service quality. So the service functions can be held during the Covid-19 pandemic.

As a solution, is carried out with reference to existing policy instruments, including: (1) Permendagri No. 7/2019 regarding Online Adminduk Services; and (2) Letter the Ministry of Home Affairs No. 443.1/2978/Dukcapil dated March 16, 2020, concerning the population administration service and Covid-19 prevention.

Permendagri No. 7/2019 regulates, that the online Adminduk service is the process of managing population documents in which the required documents are sent using web-based electronic media by utilizing technology, communication, and information facilities. The contents of these regulations includes: (1) scope of Dukcapil registration services; (2) use of electronic forms; (3) how to provide online Adminduk services, including services in case residents cannot use the online Adminduk facility; (4) online Adminduk service kiosk; and (5) the process of providing electronic signatures (TTE) of population documents; and (6) performance mechanisms; facilities and infrastructure. 
The Letter of Directorate General Dukcapil, Ministry of Home Affairs No. 443.1/2978/ Dukcapil dated March 16, 2020, concerning Adminduk Services and Virus Corona (Covid-19) Prevention was sent to address the Head of Population and Civil Registry (Dukcapil) office Province and Regency/City.

This letter consists of some instructions to conduct for Adminduk services efficiently and effectively during the Covid-19 pandemic. This letter instructed: (1) Maintain distance, do not meet, social distancing measures. Reduce physical contact; (2) Prepare a thermal gun to measure the body temperature of employees/ guests; (3) applying a clean lifestyle, cleaning the equipment/ room with disinfectant. Officer/ customer washing hands with hand sanitizer/ soap; (4) Changing work patterns to prevent viruses, not shaking hands, optimizing information and communication technology using smartphones.

And then, (5) The Head of Service enters the office to guarantee services and regulates officials/ staff who work from home and who enter the office. (6) Prioritize online services, documents are sent online in pdf format and residents print at home. Applications Dukcapil print HVS-A4 / 80-gram paper documents; (7) The Head of Service announces that the public is postponing document affairs for the next 2-3 weeks. People who need documents for the hospitals, military registration is done online, via WhatsApp and SMS; (8) especially for direct physical contact, e-ID card recording, is postponed - except for those that are urgent. When handled, use the Covid-19 prevention protocols.

Implementation, Dukcapil office doing online Adminduk services during the Covid19 pandemic in various ways, covering: play-store, website, WA, and SMS. They are in total 487 Dukcapil offices (Menpan.go.id, 2020). Based on this total, although it has not yet reached all total covering 518 Dukcapil offices both regencies and cities; but the percentage is very high, reaching $96 \%$. So, almost all of these Dukcapil offices both regencies and cities have implemented online Adminduk services during the Covid-19 pandemic.

And the other, $4 \%$ of the Dukcapil office did not have an online service application. This dukcapil office is expected to move step by step towards online services, to improve the quality of adminduk services (Gatra.com, 2020). The trick, is to copy (replicated) the innovation of Adminduk services during the Covid-19 pandemic which has been successful at other Dukcapil offices. 
The relevant studied showed, those studied on service innovations during the Covid19 pandemic were still rare. Those studied, namely: (1) Understanding the Leadership Style of the Minister of Education and Culture and Innovation by the Ministry of Education and Culture in Handling Covid-19: A Literature Study, by Ferryno, M.H. (2020); and (2) Innovation of the Mosque Donation Model through the Application of Financial Technology in the Covid-19 Pandemic Era, by Wisandiko, F.A. and Tias A.I. (2020). So, those study on

public service innovations during the Covid-19 pandemic are still rare, because those problems are new and are still ongoing today.

The field or locus of those studied was different with this study. Because, this study about the innovation of Adminduk service. While, other studies about the innovation of educational services; and about the innovation of non-profit service, namely mosque donations. Nevertheless those previous studied have similarities with this study in the focus of service innovation during the Covid-19 pandemic.

In connection with these problems, it is urgent to conduct a study on Adminduk service innovation during the Covid-19 pandemic. And then, to find out innovation by the Dukcapil office. A problem formulation as a research question as follows, what is innovation of Adminduk service can make by Dukcapil offices during the Covid-19 pandemic? The purpose of this study is to find out the innovation of Adminduk services by Dukcapil offices during the Covid-19 pandemic.

The expected output of this study can be input for the Dukcapil office in the innovation of Adminduk service in the New Normal Era to rebuild the competitiveness and sustainability of Adminduk services.

\section{Methods}

This study using a library research methods. Sampling of this was taken using the Accidental sampling technique (Sugiyono, 2009) namely the technique of taking samples that were found by chance because they were suitable for use as data sources. As a sample of this research is Dukcapil offices that has innovated in Adminduk service. The number of sample is limited 15 (fifteen) Dukcapil offices spread across in Indonesia. 
Next, data collection is carried out used written, printed, and electronic media including the internet website, like reference, documents, information, and data which relevant. The data collected are innovations made by Dukcapil offices during the Covid-19 pandemic. Data processing was done by identifying data according to the group according to focus of this study. The results are presented in the table.

Furthermore, qualitative descriptive data analysis was carried out to draw a conclusion about the innovation of Adminduk service were made by Dukcapil offices during the Covid-19 pandemic. The study was conducted in the second quarter of 2020.

\section{Results and Discussion}

The result of this study showed, the Dukcapil offices of the provincial and regency/ city governments carried out innovative Adminduk services during the Covid-19 pandemic (see, table 1). The type of innovation was found, namely:

First, an online service innovation. Innovation in processing population documents, which sends the required files using web-based electronic media by utilizing technology, communication, and information facilities. These facilities include WhatsApp and Facebook.

Second, service innovation with health protocols. This Innovation Adminduk document management process by implementing health protocols. The health protocol is carried out by implementing social \& physical distancing (maintaining distance and limiting employees from coming to work), and spraying disinfectants.

Third, pick up the ball innovation. This Adminduk service innovation through distributing documents them to the population concerned. Shuttleball innovations vary in each region. The form of pick up the ball innovation, namely: recording e-ID Card directly in their special place, for the elderly, disabled, and seriously ill during the Covid-19 period; and distributing Adminduk documents (e-ID Card) directly to people's homes. Pick up the ball innovation was carried out by the Dukcapil office in collaboration with PT Pos Indonesia and cooperating with a motorcycle taxi. 
Table 1.

Population Administration Service Innovation During the Covid-19 Pandemic

Agency Innovation (Name) Type

\section{Provincial Government}

1. DKI Jakarta Alpukat Betawi (Akses langsung layanan. Kependudukan cepat, An online and akurat untuk meng-input data bayi): an online services, health health protocol facilities data content, the results are delivered.

\section{City Government}

2. Denpasar Taring Disdukcapil (Registering through an online, social and physical distancing during Covid-19 pandemic).

3. Bogor

4. Makassar

Anonymous: Service recording e-ID Card directly in a special Pick up the ball place for the elderly people, disabled and seriously ill residents

Anonymous: Online Adminduk service for printing family An online
An online and health protocol cards and birth certificates at home

\section{Regency Government}

5. Agam

Pak Dewa (Pelayanan Adminduk dengan Whatsapp): Adminduk An online Service with Whatsapp.

6. Padang

Layanan Nagita (Layanan Nagari

Go

Digital):

An online and

Pariaman Dukcapil
application

7. Sukabumi

Mopeling Sarasa (Motor Pelayanan Keliling Saba Rahayat Desa)

An online, pick

Pick up the ball service via WA, online website, health protocols up the ball, and \& disinfectant spraying health protocol

8. Bandung Silayung (Sistem pelayanan antar langsung): Adminduk Pick up the ball Barat documents are delivered to the applicant's house

9. Penajam Paser Aplikasi Go PPU (Go Penajam Paser Utara):Online Adminduk An online Utara service, through the application on the Play-store, the results can be printed-out directly at home.

10. Bener Anonymous: Online services through Village Registration An online, and Meriah Officers and Whatsapp, preventing queues for demographic health protocol documents, social \& physical distancing

11. Cilacap Anonymous: The cooperation between Disdukcapil and PT Pos Pick up the ball Indonesia distributes e-ID Card directly to customer homes

12. Trenggalek

Anonymous: Blojek collaborates with innovation to speed up Pick up the ball service delivery of Adminduk documents and health protocols

13..Buleleng Anonymous: Online Adminduk service, spraying disinfectants, implementing social distancing to break the chain of viruses.

An online, and health protocol 
14. Maluku Barat Daya

15. Teluk Bintuni
Anonymous: Adminduk online services via Whatsapp and An online, and social media mobile to village

Pick up the ball

Anonymous: Adminduk service online via WhatsApp and An online Facebook during emergency response

Source: Bogorupdate.com; Balipost.com; Disdukcapil.cilacapkab.go.id; Drka.acehprov.go.id; Kaltim.antaranews.com; Liputan6.com; Pasundanekspres.co; Portal.sukabumikota.go.id; Posmetropadang.co.id; Sipp.menpan.go.id; Sonora.id; Sumbar.antaranews.com; Taburapos.com; Trenggalekkab.go.id; Wartamaluku.com (2020), data processed.

This innovation is one form of service innovation that prioritizes an online aplication during the Covid-19 pandemic by implementing health protocols to prevent the development of the pandemic. So, the Covid-19 pandemic problems and policy changes are driving factors for the Dukcapil office to find solutions through innovation.

The result of this study illustrated a pattern of relationship between the Covid-19 pandemic problems and policy changes to solve problems through the innovation of Adminduk service during the Covid-19 pandemic. Types the innovation of Adminduk service are carried out, namely: (1) an online innovation; (2) application of health protocols; and (3) pick up the ball innovation. This innovation was carried out to ensure that Adminduk's services are good function.

After that, Adminduk service innovation during the existing Covid-19 pandemic, can be used as an input to innovate Adminduk services in the New Normal Era to rebuild competitiveness and sustainability of Adminduk service delivery.

\section{Conclusion}

The results of this study found, that innovations in population administration services during the pandemic, in 3 (three) types, namely an online application, health protocol, and pick up the ball innovation.

The relevant Dukcapil officies need to copying or replicating an alternative type of public service innovations in accordance with local conditions to overcome the pandemic constraints and use as input for the new-normal era. 


\section{References}

Balipost.com. (2020, June 8). Ini 10 Jenis Layanan. July 29, 2020, retrieved from https://www.balipost.com/news/2020/06/08/128045/Ini,10-Jenis-Layanan-

Disdukcapil...html

Bogorupdate.com. (2020, July 17). Bima Tinjau Langsung Pelayanan Jemput Bola Rekam dan Cetak e-KTP. July 29, 2020, retrieved from https://bogorupdate.com/bogor-raya/bimatinjau-langsung-pelayanan-jemput-bola-rekam-dan-cetak-e-ktp/

Disdukcapil.cilacapkab.go.id. (2020, May 13). Disdukcapil Kabupaten Cilacap bekerjasama dengan PT Pos Indonesia. July 29, 2020, retrieved from disdukcapil.cilacapkab.go.id

Drka.acehprov.go.id. (2020). Dukcapil Bener Meriah Berhasil Terapkan Physical Distancing. July 29, 2020, retrieved from https://drka.acehprov.go.id/berita/kategori/umum/dukcapil-bener-meriah-berhasilterapkan-physical-distancing

Dyer, J. (2013) The Inovator's DNA-Mastering the Five Skill of Disruptive Innovators. Penerjemah: Cornelius Trihendardi. Yogyakarta: Penerbit Andi.

Ferryno, M.H. (2020). Memahami Gaya Kepemimpinan Menteri Pendidikan. dan Kebudayaan dan Inovasi yang dilakukan Kementerian Pendidikan dan Kebudayaan Dalam Penanganan Covid-19: Sebuah Studi Literatur, JPLN (Journal of Public Policy and Applied Administration), 2(1), Jakarta: STIA-LAN.

Fontana, A. (2011). Innovate We Can! Bekasi: Cipta Inovasi Sejahtera.

Gatra.com (2020, April 18). Layanan Online di 467 Disdukcapil Saat Wabah Covid-19. May 14, 2020, retrieved from https://www.gatra.com/detail/news/475960/teknologi/layananonline-di-467-disdukcapil-saat-wabah-covid-19

Kaltim.antaranews.com. (2020, June, 24) Disdukcapil Penajam Terapkan Pelayanan Adminduk Daring. July 29, 2020, retrieved from https://kaltim.antaranews.com/berita/80715/disdukcapil-penajam-terapkanpelayanan-adminduk-daring

Liputan6.com. (2020, May 11). Pandemi Corona Dukcapil DKI Cetak Ribuan Dokumen Secara Online. July 29, 2020, retrieved from https://www.liputan6.com/news/read/4250415/pandemi-corona-dukcapil-dki-cetakribuan-dokumen-secara-online 
LIPI. (2020). Pandemi Covid-19 dalam Perspektif Kajian Sosial: Dari PSBB sampai Kenormalan Baru. June 25, 2020, retrieved from http://kependudukan.lipi.go.id/id/berita/seputar-kegiatan-ppk/989-pandemi-covid19-dalam-perspektif-kajian-sosial-dari-psbb-sampai-kenormalan-baru Menpan.go.id. (2020) Menpan Go Digital Semakin Optimal Selama Pandemi. May 14, 2020, retrieved from https://www.menpan.go.id/site/berita-terkini/dukcapil-go-digitalsemakin-optimal-selama-pandemi

Mulgan, G. and Albury, D. (2003) Innovation in the Public Sector, 2003.

Nasution, A.H. and Kartajaya H. (2018). Inovasi. Yogyakarta: Penerbit Andi.

OECD. (2019). Regional Innovation. June 15, 2020, retrieved from http://www.oecd.org/governance/regional-policy/regionalinnovation.htm

Pasundanekspres.co. (2020, March 26). Di Tengah Wabah Corona Pelayanan Publik Tetap Prima. July 29, 2020, retrieved from https://www.pasundanekspres.co/jabar/bandung/ditengah-wabah-koronapelayanan-publik-tetap-prima/

Portal.sukabumikota.go.id. (2020). Disdukcapil Sesuaikan Layanan Untuk Cegah Penyebaran Covid-19. July 29, 2020, retrieved from https://portal.sukabumikota.go.id/12991/disdukcapil-sesuaikan-layanan-untukcegah-penyebaran-covid-19/

Posmetropadang.co.id. (2020, May 12). Covid-19 Masih Menghantui Disukcapi Tetap Monev. July 29, 2020, retrieved from https://posmetropadang.co.id/covid-19-masihmenghantui-disdukcapil-tetap-monev/

Saparita R. (2015). Membangun Inovasi untuk Kesejahteraan Masyarakat. Jakarta: Lipi Press, 2015.

Sipp.menpan.go.id. (2020). Pelayanan Adminduk Di Saat Pandemi Corona. July 29, 2020, retrieved from https://sipp.menpan.go.id/berita/detil/dinas-kependudukan-danpencatatan-sipil-kabupaten-buleleng/pelayanan-adminduk-di-saat-pandemi-corona Sonora.id. (2020, June 19). https://www.sonora.id/read/422204122/discapil-kota-makassarhadirkan-inovasi-baru-pada-layanan-online-selama-pancemi-covid-19?page=2

Sugiyono. (2009). Metode Penelitian Kuantitatif. Alfabeta. 
Sumbar.antaranews.com. (2020, June 27). Disdukcapil Agam Terbitkan 16071 Dokumen Selama PSBB Covid-19. July 29, 2020, retrieved from https://sumbar.antaranews.com/berita/368434/disdukcapil-agamterbitkan16071dokumen-selama-psbb-covid-19

Taburapos.com. (2020, April 19). Selama Tanggap Darurat Covid-19 Disdukcapilo Teluk Bintuni Buka Pelayanan Secara Online. July 29, 2020, retrieved from https:/taburapos.com/2020/04/19/selama-tangap-darurat-covid-19-disdukcapil-telukbintuni-buka-pelayanan-secara-online/

Tempo (2020). Kematian Global Akibat Covid-19 Tembus Setengah Juta Jiwa. June 30, 2020, retrieved from https://koran.tempo.co/read/internasional/454713/kematian-globalakibat-covid-19-tembus-setengah-juta-jiwa

Trenggalekkab.go.id. (2020) Pemkab Trenggalek berinovasi gandeng Blojek untuk layanan pengiriman dokumen adminduk. July 29, 2020, retrievedd from https://www.trenggalekkab.go.id/berita.php?page $=620$

Utomo, T.W.W. (2017). Inovasi Pelayanan Administrasi Kependudukan. June 22, 2020, retrieved from https://www.slideshare.net/triwidodowutomo/inovasi-pelayananadministrasi-kependudukan

Wartamaluku.com. (2020, July 15). Inovasi Layanan Whatsapp Sukses Dukcapil Maluku Barat Daya Antar Dokumen ke Pemohon. July 29, 2020, retrieved from https://www.wartamaluku.com/inovasi-layanan-whatsapp-sukses-dukcapil-mbdantar-dukumen-ke-pemohon/

Wisandiko, F.A. dan Tias, A.I. (2020). Inovasi Model Donasi Masjid Melalui Penerapan Financial Technology di Era Pandemi Covid-19, Ajim (Airlangga Journal of Innovation Management), Surabaya: Universitas Airlangga. 